\title{
ORIGINAL
}

\section{Role of total lung stress on the progression of early COVID-19 pneumonia}

\author{
Silvia Coppola ${ }^{1}$, Davide Chiumello ${ }^{1}$, Mattia Busana², Emanuele Giola ${ }^{2}$, Paola Palermo², Tommaso Pozzi ${ }^{1}$, \\ Irene Steinberg ${ }^{2}$, Stefano Roli ${ }^{1}$, Federica Romitti ${ }^{2}$, Stefano Lazzari ${ }^{2}$, Simone Gattarello², Michela Palumbo ${ }^{2}$, \\ Peter Herrmann' ${ }^{2}$, Leif Saager ${ }^{2}$, Michael Quintel ${ }^{2,3}$, Konrad Meissner $^{2}$, Luigi Camporota ${ }^{4}$, John J. Marini ${ }^{5}$, \\ Stefano Centanni ${ }^{6}$ and Luciano Gattinoni $2^{*}$ (1)
}

(c) 2021 The Author(s)

\begin{abstract}
Purpose: We investigated if the stress applied to the lung during non-invasive respiratory support may contribute to the coronavirus disease 2019 (COVID-19) progression.

Methods: Single-center, prospective, cohort study of 140 consecutive COVID-19 pneumonia patients treated in high-dependency unit with continuous positive airway pressure $(n=131)$ or non-invasive ventilation $(n=9)$. We measured quantitative lung computed tomography, esophageal pressure swings and total lung stress.
\end{abstract}

Results: Patients were divided in five subgroups based on their baseline $\mathrm{PaO}_{2} / \mathrm{FiO}_{2}$ (day 1): non-CARDS (median $\mathrm{PaO}_{2} / \mathrm{FiO}_{2} 361 \mathrm{mmHg}$, IQR [323-379]), mild (224 mmHg [211-249]), mild-moderate (173 mmHg [164-185]), moderate-severe (126 mmHg [114-138]) and severe $(88 \mathrm{mmHg}$ [86-99], $p<0.001)$. Each subgroup had similar median lung weight: $1215 \mathrm{~g}$ [1083-1294], 1153 [888-1321], 968 [858-1253], 1060 [869-1269], and 1127 [937-1193] ( $p=0.37)$. They also had similar non-aerated tissue fraction: 10.4\% [5.9-13.7], 9.6 [7.1-15.8], 9.4 [5.8-16.7], 8.4 [6.7-12.3] and 9.4 [5.9-13.8], respectively $(p=0.85)$.

Treatment failure of CPAP/NIV occurred in 34 patients (24.3\%). Only three variables, at day one, distinguished patients with negative outcome: $\mathrm{PaO}_{2} / \mathrm{FiO}_{2}$ ratio (OR $\left.0.99[0.98-0.99], p=0.02\right)$, esophageal pressure swing (OR 1.13 [1.01$1.27], p=0.032$ ) and total stress (OR 1.17 [1.06-1.31], $p=0.004$ ). When these three variables were evaluated together in a multivariate logistic regression analysis, only the total stress was independently associated with negative outcome (OR 1.16 [1.01-1.33], $p=0.032$ ).

Conclusions: In early COVID-19 pneumonia, hypoxemia is not linked to computed tomography (CT) pathoanatomy, differently from typical ARDS. High lung stress was independently associated with the failure of non-invasive respiratory support.

Keywords: COVID-19, ARDS, Non-invasive respiratory support, Lung stress, Mechanical ventilation, Computed tomography scan, Ventilation-induced lung injury

\footnotetext{
*Correspondence: gattinoniluciano@gmail.com

2 Department of Anesthesiology, Medical University of Göttingen,

University Medical Center Göttingen, Robert Koch Straße 40,

37075 Göttingen, Germany

Full author information is available at the end of the article
}

\section{重




\section{Introduction}

Pneumonia associated to coronavirus disease 2019 (COVID-19) is considered a form of acute respiratory distress syndrome (ARDS) when it meets ARDS criteria [1] $\left(\mathrm{PaO}_{2} / \mathrm{FiO}_{2}\right.$ ratio below $300 \mathrm{mmHg}$ at PEEP of 5 $\mathrm{cmH} 2 \mathrm{O}$ or more associated with bilateral X-ray infiltrates). Accordingly, many hospitalized patients are classified as COVID-19 ARDS (CARDS). However, frequent discrepancies between the severity of oxygenation impairment, the relatively maintained lung mechanics $[2$, $3]$, together with atypical lung imaging raises the question whether the CARDS pathophysiology is really similar to that of ARDS from other etiologies [4]. To select appropriate treatment, in particular the use of positive end-expiratory pressure (PEEP), understanding the characteristics of the underlying pathology is crucial. Indeed, in heavy and edematous lungs PEEP usually facilitates better oxygenation by maintaining open those unstable lung units, therefore, preventing atelectasis [5]. Such features and mechanisms have been well-known characteristics of typical ARDS since its original description [6]. However, the undelaying pathophysiology of CARDS is fundamentally different, particularly during the early clinical stages, because CARDS lacks extensive edema and atelectasis. Consequently, customary levels of PEEP may simply increase the stress applied to the lung. During spontaneous breathing, total lung stress is the sum of the transpulmonary pressures generated by the patient and by the end-expiratory airway pressure [7]. Acting together during vigorous breathing, these components may promote patient self-induced lung injury (P-SILI) [8-10]. Indeed, the level of total lung stress per cycle, the breathing frequency and the total time of its application have the potential to cause further lung deterioration [11].

In the current study, our aim was to answer the following questions: (1) Is the degree of hypoxemia determined by the same mechanisms as in typical ARDS (i.e., edema and atelectasis)? (2) Is total lung stress a contributing factor of clinical progression in spontaneously breathing patients?

To address these questions, we evaluated the anatomical features of the lung using quantitative computed tomography $(\mathrm{CT})$ and determined total lung stress by estimating transpulmonary pressure.

\section{Methods}

\section{Patient population}

Out of 2044 laboratory-confirmed COVID-19 patients treated in the emergency department of ASST Santi Paolo e Carlo, San Paolo Hospital, Milan between September 2020 and March 2021, 998 were discharged home

\section{Take-home message}

Despite fully fitting the ARDS Berlin definition, the COVID-19 pneumonia in its early phase presents pathoanatomical characteristics which make the presently recommended treatment (high PEEP) highly questionable and potentially harmful.

and 1046 were admitted to the hospital. Depending on the severity of the disease, 606 were admitted to COVID19 ward, 37 were immediately transferred to the intensive care unit (ICU) and 403 to two COVID-19 high-dependency units. For logistic reasons, only one of the two high-dependency unit was involved in the study, and no exclusion or inclusion criteria were applied. Hence, 140 adult patients ( $>18$ years of age) with COVID-19 pneumonia confirmed by CT were consecutively studied (see Fig. S1 for patients' selection flowchart).

The standard treatment in the high-dependency unit from which a patient was enrolled, consisted of the initial treatment with CPAP (PEEP 5, 7.5 or $10 \mathrm{cmH}_{2} \mathrm{O}$ ), delivered through helmet or mask. At the time of the study, high-flow nasal cannula was not used in the highdependency unit. The study was observational, and no interventions other than those of standard treatment were applied. The study was approved by the local ethical board (Comitato Etico Milano Area I; 17263/2020-2020/ $\mathrm{ST} / 095)$, and informed consent was acquired from each patient.

\section{Protocol}

At day 1 (first day in high-dependency unit, HDU), each patient underwent:

1. A lung CT scan at atmospheric pressure during spontaneous breathing, in room air.

2. After the transfer to the HDU, an esophageal balloon catheter was inserted for the measurement of tidal pleural pressure swings [12]. The radio-opaque esophageal catheter was configured with a balloon in its lower portion and introduced into the lower third of the esophagus at a depth between 35 and $40 \mathrm{~cm}$ from the nose. All tracings were processed and displayed on a dedicated data acquisition system (Optivent SIDAM Srl, Modena, Italy), see Fig. S2 in supplementum. The proper position of the esophageal balloon was assessed daily by confirming the presence of the cardiac artefact on the monitored tracing.

3. Respiratory support was provided by helmet continuous positive airway pressure (CPAP) or by maskdelivered non-invasive ventilation (NIV) [13]. The non-invasive respiratory support settings [inspired 
oxygen fraction $\left(\mathrm{FiO}_{2}\right)$, PEEP and pressure support (PS)] were adjusted, as needed, to values chosen by the attending physician to maintain the peripheral oxygen saturation $\left(\mathrm{SpO}_{2}\right)>92 \%$.

4. PEEP test: On day 1 after admission, a formal PEEP test was performed in 121 patients with helmet. Peripheral oxygen saturation $\left(\mathrm{SpO}_{2}\right)$, respiratory rate, and esophageal pressure swings were measured at 0 and $10 \mathrm{cmH}_{2} \mathrm{O}$ of PEEP, 10 min apart.

5. Patients were classified into five groups according to the revised Berlin definition of ARDS [14]: nonCARDS $\left(\mathrm{PaO}_{2} / \mathrm{FiO}_{2}>300 \mathrm{mmHg}\right)$, mild CARDS $\left(200 \mathrm{mmHg}<\mathrm{PaO}_{2} / \mathrm{FiO}_{2}<300 \mathrm{mmHg}\right.$ ), mild-moderate CARDS $\left(150 \mathrm{mmHg}<\mathrm{PaO}_{2} / \mathrm{FiO}_{2}<200 \mathrm{mmHg}\right.$ ), moderate-severe CARDS $\left(100 \quad \mathrm{mmHg}^{2}<\mathrm{PaO}_{2} /\right.$ $\left.\mathrm{FiO}_{2}<150 \mathrm{mmHg}\right)$ and severe CARDS $\left(\mathrm{PaO}_{2} /\right.$ $\mathrm{FiO}_{2}<100 \mathrm{mmHg}$ ).

\section{During treatment}

From day 1 to the end of the study period, the patients underwent daily the recording of vital signs, Borg scale dyspnea score, laboratory parameters, non-invasive respiratory support settings, respiratory rate, esophageal pressure swing, and arterial blood gas analysis. All measurements were taken in supine position. If prone position was used, these measurements were taken $\geq 3 \mathrm{~h}$ after resupination.

The study positive outcome was defined as the ability of the patient to sustain $\mathrm{PaO}_{2} / \mathrm{FiO}_{2}>200 \mathrm{mmHg}$, respiratory rate $<20-22 / \mathrm{min}$, and $\mathrm{PaCO}_{2}>35 \mathrm{mmHg}$ for $>24 \mathrm{~h}$ without non-invasive respiratory support. The negative outcome was defined as the decision to transfer to the intensive care unit for immediate intubation and application of mechanical ventilation. These decisions were made at the discretion of the attending physician on a clinical basis. The reasons that led to the decision to intubate were detailed in the clinical record (see Supplementum for details).

\section{Measurements}

1. Lung weight, lung gas-volume and the fractions of the over-, normally, poorly and non-aerated tissues using quantitative analysis of the whole-lung CT scan.

2. Esophageal pressure swing (i.e., the spontaneous inspiratory effort), measured as the maximal negative deflection of the esophageal pressure from the endexpiratory value.

3. Total lung stress $\left(\mathrm{P}_{\mathrm{L}}\right)$, computed as:

$$
P_{L}=\left(\Delta P_{a w}-\Delta P_{e s}\right)+(\operatorname{PEEP} \cdot 0.7) .
$$

In this equation $P_{L}$ is the maximal transpulmonary pressure, defined as the total stress applied to the lung.
$\Delta P_{e s}$ is the tidal esophageal pressure swing, $\Delta P_{a w}$ is the pressure support applied during NIV and 0.7 is the estimated fraction of airway pressure transmitted to the lung $[15,16]$. For the full derivations see Supplement [17].

\section{Statistical analysis}

The normal distribution of the variables was assessed with Shapiro-Wilk test. Data are expressed as mean \pm standard deviation or median [interquartile range], as appropriate. Comparison between two means or medians was performed with Student's $t$ test or Wilcoxon's test. Oneway analysis of variance or Kruskal-Wallis test was used to compare multiple means or medians. Chi-square test or Fisher's exact test were used to construct the contingency tables. To assess the effect of time on $\mathrm{PaO}_{2} / \mathrm{FiO}_{2}$ ratio and total stress, and the association between study variables and outcomes, a logistic regression model was modeled. Two-tailed $p$ values $<0.05$ were considered statistically significant. All analyses were performed with $\mathrm{R}$ for Statistical Computing 4.0.

\section{Results}

\section{Standard treatment}

Following the local protocol, all patients admitted to the high-dependency unit were treated with helmet CPAP $\left(5-10 \mathrm{cmH}_{2} \mathrm{O}\right)$ in the awake prone position. Patients received dexamethasone $6 \mathrm{mg}$ per day for five consecutive days (September 2020 to January 2021). After publication of the Recovery Trial (February 2021) [18] the treatment was continued up to 10 days if the patient was not improving. Low molecular weight heparin was administered daily. Antibiotics were administered only for confirmed bacterial infection. All the measurements were obtained in supine position.

\section{Anatomical and physiological characteristics of CARDS}

In Table 1 , we present the main baseline clinical characteristics of the study population, divided into the five aforementioned subgroups. Apart from height, all other anthropometric and clinical characteristics were similar among all five subgroups. The proportion of patients that failed non-invasive support-and were subsequently ventilated invasively-was higher for the severe category, compared to the other subgroups. Similarly, the in-hospital mortality rates were significantly higher among patients with moderate-severe and severe CARDS. Death occurred only in invasively ventilated patients.

In Fig. 1, we report the $\mathrm{PaO}_{2} / \mathrm{FiO}_{2}$ (Panel A) and the associated CT scan anatomical features for the five subgroups. As shown, the $\mathrm{PaO}_{2} / \mathrm{FiO}_{2}$ ratio ranged widely, from $477 \mathrm{mmHg}$ down to $76 \mathrm{mmHg}$. In contrast, as shown in Panel B, the lung weight and the fractions of well, poorly, and non-inflated tissue as well as the CT 
Table 1 Clinical characteristics and laboratory analysis of the ARDS severity subgroups

\begin{tabular}{|c|c|c|c|c|c|c|c|}
\hline & $\begin{array}{l}\text { Overall } \\
(n=140)\end{array}$ & $\begin{array}{l}\text { No ARDS } \\
(n=17)\end{array}$ & $\begin{array}{l}\text { Mild ARDS } \\
(n=45)\end{array}$ & $\begin{array}{l}\text { Mild-mod- } \\
\text { erate ARDS } \\
(n=33)\end{array}$ & $\begin{array}{l}\text { Moderate- } \\
\text { severe ARDS } \\
(n=36)\end{array}$ & $\begin{array}{l}\text { Severe ARDS } \\
(n=9)\end{array}$ & $p$ value \\
\hline \multicolumn{8}{|l|}{ Anthropometrics } \\
\hline Female ( $n \%)$ & $42(30)$ & $2(12)$ & $11(24.4)$ & $12(36.4)$ & $13(36.1)$ & $4(44.4)$ & $<0.001^{*}$ \\
\hline Age (years) & $59[52-66]$ & 58 [54-62] & 59 [53-67] & 57 [51-63] & 60 [55-65] & 63 [57-69] & 0.11 \\
\hline $\mathrm{BMI}\left(\mathrm{kg} / \mathrm{m}^{2}\right)$ & $28.1[25.2-32.3]$ & $29.4[27.8-33.2]$ & $28.0[25.3-33.7]$ & 26.0 [24.4-29.6] & 29 [25.9-32.3] & $28.1[27.8-30.1]$ & 0.98 \\
\hline Height (m) & $1.7 \pm 0.09$ & $1.77 \pm 0.09$ & $1.73 \pm 0.07$ & $1.67 \pm 0.12$ & $1.67 \pm 0.09$ & $1.77 \pm 0.08$ & $0.006^{*}$ \\
\hline $\begin{array}{l}\text { Duration of symp- } \\
\text { toms to admis- } \\
\text { sion (days) }\end{array}$ & $6[4-8]$ & $7[5-10]$ & $5[4-8]$ & $6[3-8]$ & $6[5-8]$ & $5[2-7]$ & 0.56 \\
\hline CPAP-NIV $(n-n)$ & $131-9$ & $16-1$ & $43-2$ & $30-3$ & $34-2$ & $8-1$ & 0.90 \\
\hline $\begin{array}{l}\text { Days from admis- } \\
\text { sion to intubation } \\
\text { (days) }\end{array}$ & $6[4-9]$ & $6[4-7]$ & $4[4-6]$ & $5[5-10]$ & $8[6-12]$ & $6[3-8]$ & 0.25 \\
\hline $\begin{array}{l}\text { Failure of non-inva- } \\
\text { sive respiratory } \\
\text { support ( } n \%)\end{array}$ & 34 [24.3] & $3(17.6)$ & $7(15.6)$ & $7(21.2)$ & $10(27.8)$ & $7(77.8)$ & $0.002^{*}$ \\
\hline $\begin{array}{l}\text { In-hospital mortal- } \\
\text { ity }(n \%)\end{array}$ & $14(10)$ & $1(5.9)$ & $1(2.2)$ & $1(3.0)$ & $7(19.4)$ & $4(44.4)$ & $<0.001^{*}$ \\
\hline \multicolumn{8}{|l|}{ Laboratory } \\
\hline Hemoglobin (g/dl) & 14.4 [13.2-15.4] & 14.6 [13.7-15.5] & $14.3[13.2-15.4]$ & 14 [13-15] & $14.5[13.9-15.4]$ & $14.6[12.9-16.2]$ & 0.56 \\
\hline Platelets $\left(10^{9} / \mathrm{I}\right)$ & 202 [155-241] & 205 [183-266] & 202 [163-247] & 204 [159-223] & 194 [139-239] & 158 [150-218] & 0.51 \\
\hline D-dimer (ng/dl) & 298 [215-411] & 251 [172-366] & 301 [223-386] & 263 [210-391] & 287 [196-429] & 434 [344-457] & 0.49 \\
\hline INR & 1.14 [1.09-1.22] & 1.13 [1.08-1.16] & 1.14 [1.08-1.23] & 1.15 [1.09-1.22] & 1.18 [1.12-1.25] & $1.13[1.1-1.21]$ & 0.41 \\
\hline aPTT (s) & 1.01 [0.92-1.08] & $1.05[0.92-1.11]$ & $1.00[0.93-1.06]$ & $1.04[0.94-1.1]$ & 0.99 [0.91-1.07] & $0.95[0.93-1.1]$ & 0.76 \\
\hline $\mathrm{ALT}(\mathrm{U} / \mathrm{I})$ & $44[28-67]$ & $47[36-79]$ & $49[30-73]$ & 46 [32-62] & $32[27-65]$ & $30[23-47]$ & 0.23 \\
\hline AST (U/I) & 55 [41-76] & 59 [43-96] & 59 [42-77] & $53[41-74]$ & $52[39-71]$ & $56[37-72]$ & 0.87 \\
\hline Creatinine (mg/dl) & $0.8[0.7-1]$ & 0.85 [0.78-1.13] & $0.85[0.7-1]$ & $0.8[0.6-0.98]$ & $0.9[0.73-1.1]$ & $1[0.68-1.10]$ & 0.32 \\
\hline
\end{tabular}

images (see also Figure S3) were strikingly similar among severity categories, independently from the degree of oxygenation impairment.

Pathophysiological features are reported in Table 2. As shown, the respiratory rate was similar in all CARDS subgroups, regardless of severity, but was significantly higher for CARDS than for the subgroup of patients with no CARDS (i.e. patients with $\mathrm{PaO}_{2} / \mathrm{FiO}_{2}$ ratio $>300 \mathrm{mmHg}$ ). The $\mathrm{PaCO}_{2}$ and dyspnea score on the Borg scale as well as the esophageal pressure swing and the total stress were almost identical for all subgroups. In Table 2, we also report the results of the PEEP test: $\mathrm{SpO}_{2}$ and respiratory rate improved only in patients with moderately severe and severe ARDS, whereas the esophageal pressure swing did not change after raising PEEP from $0 \mathrm{~cm} \mathrm{H}_{2} \mathrm{O}$ to 10 $\mathrm{cm} \mathrm{H}_{2} \mathrm{O}$ in any subgroup.

\section{Association between variables and outcome}

One-hundred and six patients (76\%) had a positive outcome, i.e., recovered and did not require any respiratory support after 10 [6-13] days from admission. No death was observed in this subgroup of 106 patients. In contrast, 34 (24\%) patients had a negative outcome, i.e., were transferred to the ICU, intubated and mechanically ventilated after 6 [4-9] days from admission. Fourteen (41.1\%), out of the 34 intubated patients, died in-hospital.

The characteristics of the patients who had positive or negative outcomes, measured at baseline (day 1), are summarized in Table 3. As shown, the two subgroups differed only by oxygenation $\left(\mathrm{PaO}_{2}, \mathrm{PaO}_{2} / \mathrm{FiO} 2\right.$ ratio) and for total lung stress. Of note, the pathoanatomical variables were almost identical in the two groups. During the PEEP test (from 0 to $10 \mathrm{cmH}_{2} \mathrm{O}$ of PEEP), the oxygenation response was not different in the two subgroups, although a tendency towards improvement was observed in the patients with negative outcome. Of note, the esophageal pressure swings did not change between 0 and $10 \mathrm{cmH} 2 \mathrm{O}$, in either subgroup. Anthropometrics, physiological and CT scan variables, as recorded at day 1 , were entered in univariate logistic regressions to evaluate their association with outcome (see Table S1). A significant association with outcome was found only for: $\mathrm{PaO}_{2} /$ $\mathrm{FiO}_{2}$ ratio $(\mathrm{OR}=0.99$ [0.98-0.99], $p=0.02)$; esophageal pressure swing $(\mathrm{OR}=1.13$ [1.01-1.27], $p=0.032)$ 


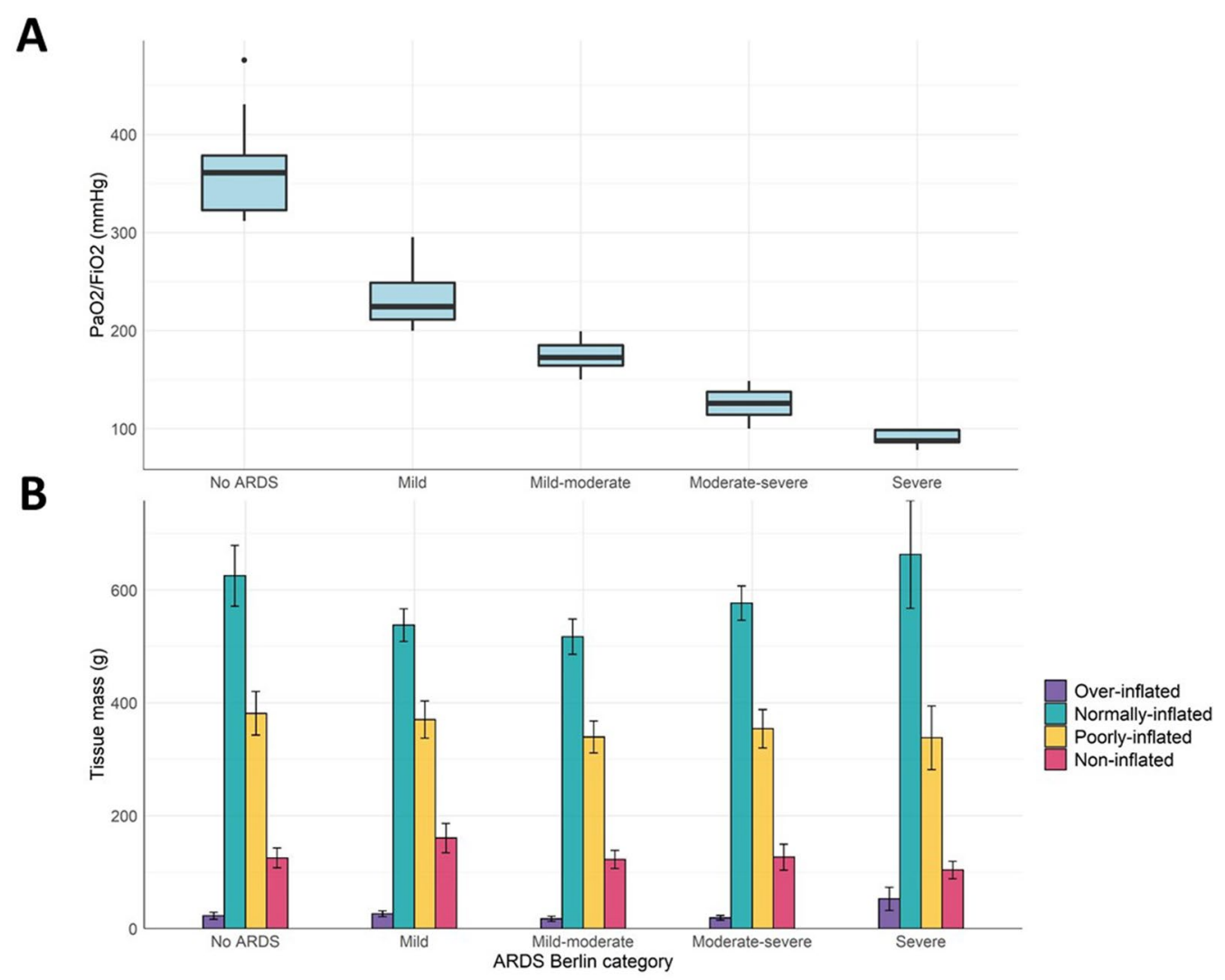

Fig. 1 Panel A: $\mathrm{PaO}_{2} / \mathrm{FiO}_{2}$ ratio measured at day 1 in the non-CARDS and CARDS subgroups $(p<0.001)$. Panel B: lung computed tomography features at day 1 as evaluated by the quantitative analysis in the five subgroups (over-inflated tissue, $p=0.30$; normally inflated tissue, $p=0.31$; poorly inflated tissue, $p=0.91$; non-inflated tissue $p=0.74$ ). The $\mathrm{PaO}_{2} / \mathrm{FiO}_{2}$ ratio decreased across the subgroups by $300 \mathrm{mmHg}$, while the associated anatomical features were nearly identical.

and total stress $(\mathrm{OR}=1.17$ [1.06-1.31], $p=0.004$, see Table S1). When these three variables were evaluated together in a multivariate logistic regression analysis, only the total stress was independently associated with negative outcome ( $\mathrm{OR}=1.16$ [1.01-1.33], $p=0.032)$.

In Fig. 2, left panel, we present the daily $\mathrm{PaO}_{2} / \mathrm{FiO}_{2}$ time course of the individual patients according to clinical outcome. As shown, the $\mathrm{PaO}_{2} / \mathrm{FiO}_{2}$ was significantly higher at baseline (see Table 3 ) and significantly increased with time (slope, $p=0.001$ ) in patients with positive outcome, compared to the patients with negative one. Likewise, in right panel, we present the time course of the total lung stress. As shown, total lung stress was significantly lower at baseline (see Table 3) and significantly decreased with time (slope, $p<0.001$ ) in patients with positive outcome, compared to the patients with a negative outcome.

The changes of total lung stress and $\mathrm{PaO}_{2} / \mathrm{FiO}_{2}$ measured the last day of the study, for the patients with positive or negative outcome are reported in Table S2. As shown, the total lung stress significantly increased in patients with negative outcome.

\section{Discussion}

Anatomical and physiological characteristics of CARDS

In this study, we investigated the specific features of COVID-19 pneumonia in a well-defined stage of the infection time course, i.e., between the admission to the high-dependency unit to the time of healing or admission to the intensive care unit. In this specific timeframe, we found that the relationship between the severity of the oxygenation impairment and the lung anatomy-as revealed by the quantitative CT scan analysis, contrasts with findings reported in the ARDS literature. Indeed, in all non-COVID ARDS studies, the decrease in $\mathrm{PaO}_{2} /$ $\mathrm{FiO}_{2}$ (i.e., greater oxygenation impairment) has been associated with the increase in lung weight and the fraction of non-aerated tissue (reflecting the inflammatory lung edema of ARDS) [19-21]. By contrast, in the present study the lung weight in moderate-severe and severe CARDS was approximately half of what has been described in typical ARDS of similar severity which primarily included bacterial infection from pneumonia and sepsis. In addition, the lung gas-volume in typical ARDS 
Table 2 Gas-exchange and PEEP test in the ARDS subgroups

\begin{tabular}{|c|c|c|c|c|c|c|c|}
\hline & $\begin{array}{l}\text { Overall } \\
(n=140)\end{array}$ & $\begin{array}{l}\text { No ARDS } \\
(n=17)\end{array}$ & $\begin{array}{l}\text { Mild ARDS } \\
(n=45)\end{array}$ & $\begin{array}{l}\text { Mild-moderate } \\
\text { ARDS }(n=33)\end{array}$ & $\begin{array}{l}\text { Moderate- } \\
\text { severe ARDS } \\
(n=36)\end{array}$ & $\begin{array}{l}\text { Severe ARDS } \\
(n=9)\end{array}$ & $p$ value \\
\hline \multicolumn{8}{|l|}{ Gas exchange } \\
\hline $\mathrm{PaO}_{2}(\mathrm{mmHg})$ & $104[79-140]$ & 226 [187-259] & 143 [102-151] & 112 [100-123] & 83.2 [75.9-93.6] & $65.1[59.3-69]$ & $<0.001^{*}$ \\
\hline $\mathrm{FiO}_{2}$ & $0.6[0.6-0.7]$ & $0.6[0.6-0.7]$ & $0.6[0.5-0.7]$ & $0.7[0.5-0.7]$ & $0.7[0.6-0.7]$ & $0.8[0.7-0.8]$ & $<0.001^{*}$ \\
\hline $\mathrm{PaCO}_{2}(\mathrm{mmHg})$ & 37 [33.9-40.7] & $38.3[32.6-42.0]$ & 35.9 [32.6-39] & 38.8 [35-41] & 36.5 [34.8-40.8] & 39 [34.2-39.9] & 0.37 \\
\hline $\mathrm{pH}$ & $7.44[7.42-7.47]$ & $7.44[7.42-7.46]$ & $7.45[7.43-7.48]$ & $7.44[7.43-7.47]$ & $7.44[7.42-7.46]$ & $7.43[7.42-7.45]$ & 0.52 \\
\hline $\begin{array}{l}\text { Respiratory rate } \\
\text { (bpm) }\end{array}$ & $20[18-24]$ & $16[15-20]$ & 21 [18-23] & $21[18-24]$ & $21[18-25]$ & $20[18-20]$ & $0.039^{*}$ \\
\hline $\operatorname{PEEP}\left(\mathrm{cmH}_{2} \mathrm{O}\right)$ & $7.5[7.5-10]$ & $10[7.5-10]$ & $8[7.5-10]$ & $8[7.5-10]$ & $9[7.5-10]$ & $10[10-10]$ & 0.24 \\
\hline $\begin{array}{l}\text { Esophageal pres- } \\
\text { sure swing (cm } \\
\left.\mathrm{H}_{2} \mathrm{O}\right)\end{array}$ & $7[5-10]$ & $6[5-7]$ & 7 [5-9] & 7 [4-9] & $9[7-12]$ & $7[5-7]$ & 0.06 \\
\hline $\begin{array}{l}\text { Total stress }(\mathrm{cm} \\
\left.\mathrm{H}_{2} \mathrm{O}\right)\end{array}$ & $14[11.5-16.3]$ & 13 [11.8-15] & $13.2[11.3-16]$ & $13.8[11-16]$ & $15.2[12.9-18.6]$ & $14[13.3-16.8]$ & 0.12 \\
\hline Borg dyspnea scale & $0[0-1]$ & $0[0-1]$ & $0[0-0]$ & $0[0-0]$ & $0[0-1]$ & $0[0-1]$ & 0.34 \\
\hline \multicolumn{8}{|l|}{ PEEP test } \\
\hline $\begin{array}{l}\mathrm{SpO}_{2} \text { at } 0 \mathrm{cmH}_{2} \mathrm{O} \\
(\%)\end{array}$ & 97 [93-99] & 98 [94-100] & 98 [96-99] & 98 [95-99] & 95 [93-98] & 91 [88-94] & $0.003^{*}$ \\
\hline $\begin{array}{l}\mathrm{SpO}_{2} \text { at } 10 \mathrm{cmH}_{2} \mathrm{O} \\
(\%)\end{array}$ & 98 [96-99] & $99[98-100]$ & 99 [97-100] & 98 [97-99] & 97 [96-98] & 94 [94-98] & $0.006^{*}$ \\
\hline $\begin{array}{l}\text { Respiratory rate at } \\
\mathrm{O} \mathrm{cm} \mathrm{H}_{2} \mathrm{O} \text { (bpm) }\end{array}$ & $22[18-28]$ & 18 [15-20] & 22 [18-28] & 23 [20-28] & 22 [19-27] & 24.5 [22-27] & $0.010^{*}$ \\
\hline $\begin{array}{l}\text { Respiratory rate at } \\
10 \mathrm{~cm} \mathrm{H}_{2} \mathrm{O}(\mathrm{bpm})\end{array}$ & 20 [16-24] & $16[15-18]$ & 20 [17-22] & 22 [18-25] & 20 [17-28] & $19.5[18-21]$ & $0.007^{*}$ \\
\hline $\begin{array}{l}\text { Esophageal pres- } \\
\text { sure swing at } 0 \\
\mathrm{cmH}_{2} \mathrm{O}\left(\mathrm{cmH}_{2} \mathrm{O}\right)\end{array}$ & $8[6-12]$ & $7[5-7]$ & $8[5-10]$ & $8[5-12]$ & $8[7-15]$ & $8.8[6-11]$ & 0.36 \\
\hline $\begin{array}{l}\text { Esophageal pres- } \\
\text { sure swing at } 10 \\
\mathrm{cmH}_{2} \mathrm{O}\left(\mathrm{cmH}_{2} \mathrm{O}\right)\end{array}$ & $7[5-10]$ & 7.5 [6-9] & 7 [5-9] & 7 [4-9] & $9[7-12]$ & 7 [6-9] & 0.07 \\
\hline $\begin{array}{l}\text { Total stress at } 0 \\
\qquad \mathrm{cmH}_{2} \mathrm{O}\left(\mathrm{cmH}_{2} \mathrm{O}\right)\end{array}$ & $8[6-12]$ & $7[5-10]$ & $8[5-10]$ & $8[5-12]$ & $8[7-15]$ & $9[6-11]$ & 0.36 \\
\hline $\begin{array}{c}\text { Total stress at } \\
10 \mathrm{cmH}_{2} \mathrm{O} \\
\left(\mathrm{cmH}_{2} \mathrm{O}\right)\end{array}$ & 14 [12-17] & 14.5 [13-16.3] & 14 [12-16] & 14 [11.3-16.3] & 16 [14-18.5] & 14 [13.4-15.6] & 0.07 \\
\hline
\end{tabular}

*Statistically significant difference between groups

is greatly reduced to the size of a "baby-lung" [22]. By contrast, in the present study the CARDS gas-volume, regardless the severity of gas exchange impairment, was around $2000 \mathrm{ml}$, i.e., 2 times greater than what has been consistently described in the ARDS literature (see Table S3 in the online supplement for a comparison with typical ARDS). We cannot exclude that other viral pneumonia present similar characteristics. Unfortunately, not sufficient data are available for any comparison. This dissociation between the gas exchange and the anatomical lung characteristics, unique to CARDS, helps answer the strongly debated question of whether CARDS should be considered an atypical form of ARDS [23-26]. No doubt exists that according to the Berlin definition, COVID-19 is classifiable as ARDS (bilateral chest X-ray infiltrates and $\mathrm{PaO}_{2} / \mathrm{FiO}_{2}$ ratio $<300 \mathrm{mmHg}$, measured in our population at a PEEP $\geq 5 \mathrm{cmH}_{2} \mathrm{O}$ ). On the other hand, there should also be no doubt, that in its early stages, CARDS is fundamentally atypical, as the severity of hypoxemia is unrelated to the severity of the anatomical lung pathology.

The mechanisms which may explain this uncoupling are conceptually straightforward: if one excludes intracardiac shunts, the only mechanism which may account for the severe hypoxemia in a lung with nearly normal gas-volume and weight is impaired or dysregulated lung perfusion. We had hypothesized this mechanism by exclusion at the very onset of the pandemic $[2,27]$. Since then, altered perfusion as a cause of hypoxemia has been increasingly recognized and documented 
Table 3 Gas-exchange and PEEP test in non-intubated versus intubated patients

\begin{tabular}{|c|c|c|c|}
\hline & Non intubated $(n=106)$ & Intubated $(n=34)$ & $p$ value \\
\hline \multicolumn{4}{|l|}{ Gas exchange } \\
\hline Respiratory rate (bpm) & 20 [18-23] & $22[19-25]$ & 0.22 \\
\hline $\mathrm{PaO}_{2} / \mathrm{FiO}_{2}(\mathrm{mmHg})$ & $197[147-245]$ & $149[106-207]$ & $0.003^{*}$ \\
\hline $\mathrm{PaO}_{2}(\mathrm{mmHg})$ & $114[85-149]$ & $86[69-124]$ & $0.004^{*}$ \\
\hline $\mathrm{PaCO}_{2}(\mathrm{mmHg})$ & $38[34-41]$ & 35 [33-39] & 0.09 \\
\hline Borg dyspnea scale & $0[0-1]$ & $0[0-1]$ & 0.08 \\
\hline Esophageal pressure swing $\left(\mathrm{cmH}_{2} \mathrm{O}\right)$ & $7[5-9]$ & $9[5-12]$ & 0.10 \\
\hline Total lung stress $\left(\mathrm{cmH}_{2} \mathrm{O}\right)$ & $13.5[11.4-15.4]$ & $15.6[13.1-19.2]$ & $0.018^{*}$ \\
\hline Tissue mass (g) & $1101[866-1284]$ & $1132[942-1260]$ & 0.39 \\
\hline Gas volume (ml) & $2191[1624-2889]$ & $2173[1563-2737]$ & 0.82 \\
\hline Overinflated tissue (\%) & $1[0-3]$ & $1[0-3]$ & 0.57 \\
\hline Normally inflated tissue (\%) & $56[45-63]$ & $53[43-65]$ & 0.43 \\
\hline Poorly inflated tissue (\%) & $32[24-38]$ & $32[25-40]$ & 0.90 \\
\hline Non-inflated tissue (\%) & $9[6-13]$ & $10[8-16]$ & 0.26 \\
\hline \multicolumn{4}{|l|}{ PEEP test } \\
\hline $\mathrm{SpO}_{2}$ at $0 \mathrm{cmH}_{2} \mathrm{O}(\%)$ & 98 [94-99] & $93[92-98]$ & $0.005^{*}$ \\
\hline $\mathrm{SpO}_{2}$ at $10 \mathrm{cmH}_{2} \mathrm{O}(\%)$ & $98[97-99]$ & $97[94-98]$ & $0.010^{*}$ \\
\hline Esophageal pressure swing at $0 \mathrm{cmH}_{2} \mathrm{O}\left(\mathrm{cmH}_{2} \mathrm{O}\right)$ & $8[6-10]$ & $12[6-15]$ & $0.007^{*}$ \\
\hline Esophageal pressure swing at $10 \mathrm{cmH}_{2} \mathrm{O}\left(\mathrm{cmH}_{2} \mathrm{O}\right)$ & $7[5-9]$ & $11[6-14]$ & $0.002^{*}$ \\
\hline Respiratory rate at $0 \mathrm{cmH}_{2} \mathrm{O}(\mathrm{bpm})$ & $21[17-28]$ & $23[20-28]$ & 0.21 \\
\hline Respiratory rate at $10 \mathrm{cmH}_{2} \mathrm{O}(\mathrm{bpm})$ & $20[16-22]$ & $20[18-25]$ & 0.16 \\
\hline
\end{tabular}

*Statistically significant difference between groups
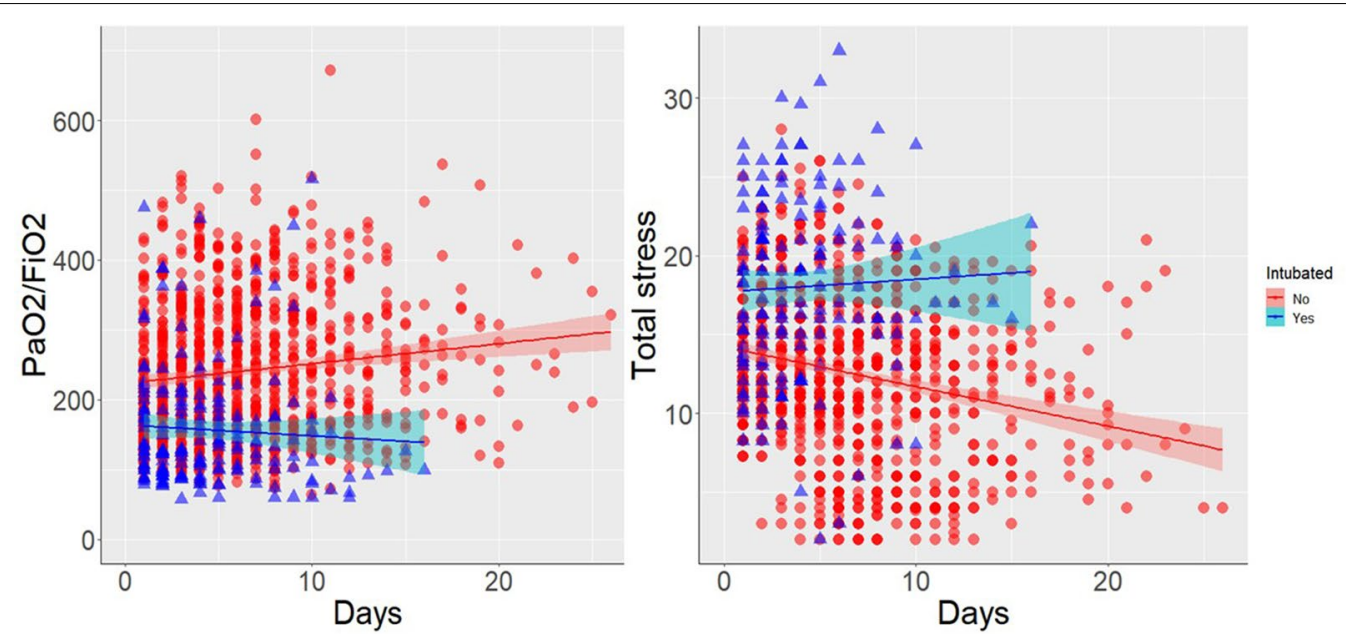

Fig. 2 Left panel: daily time course of the $\mathrm{PaO}_{2} / \mathrm{FiO}_{2}$ ratio, in the single patient, with positive outcome (red color) and negative outcome (blue color). Right panel: daily time course of the total lung stress, in the single patient, with positive outcome (red color) and negative outcome (blue color)

[28-30]. The atypical features of CARDS have been challenged by several authors who maintain-based on the average value of lung mechanics of the population-that CARDS is little different from other, more familiar forms of ARDS [23, 25, 31]. It is likely that most of these controversies stem from the inclusion of patients invasively ventilated in the later stages of the disease, when the pathological evolution of the disease makes the mechanics of CARDS more closely resemble those of typical ARDS [32]. 


\section{Negative outcome}

The assessment of the negative outcome, i.e., failure of non-invasive respiratory support, and the decision to intubate the patient, were undertaken on a clinical basis. In the supplemental results we report in detail the reasons that led to the intubation of the individual patients. As shown, they manifested progressive worsening of hypoxemia, increase in respiratory effort and delirium. The proportion of patients who were transferred from high-dependency unit to the intensive care unit was $24.3 \%$. This value is in line with what has been observed in larger population studies, in which the proportion of patients transferred to the intensive care unit is similar ( 20\%) [33].

As shown in Table 3, only three variables at day 1 distinguished patients who were eventually intubated: the $\mathrm{PaO}_{2} / \mathrm{FiO}_{2}$ ratio, the esophageal pressure swing and the total stress. The latter appears to be a more encompassing and robust variable than the esophageal pressure swing alone, as total stress includes the lung stress generated by PEEP. Of note, the total lung stress was the only variable which independently was associated with outcome in a multiple logistic regression model. However, it is still questionable if a high stress contributes to worsening of COVID-19 pneumonia or if the worsening of pneumonia contributes to an increased stress.

Tonelli et al. recently found in COVID-19 patients esophageal pressure swing values comparable to our population. The total stress was also similar as they used $10 \mathrm{cmH}_{2} \mathrm{O}$ of PEEP, as in our study [34]. As these values are remarkably lower, about half $\left(12.5\right.$ vs $32 \mathrm{cmH}_{2} \mathrm{O}$, respectively), of what they described in typical ARDS, they ruled out a relevant role of P-SILI in determining outcome in CARDS. Actually, we should note that the ventilation induced lung injury is caused by the associated strain (the relative change in volume compared to the functional residual capacity). Due to the curvilinear shape of the stress-strain relationship (analogously to the pressure-volume curve of the respiratory system) the same strain requires higher stress in the "baby" lung than in the adult lung. Therefore, the higher stress measured in typical ARDS may actually correspond to a similar strain in COVID-19 due to their large differences in lung volume and compliance.

\section{Clinical consequences}

The primary cause of oxygenation impairment in early CARDS pneumonia, instead of lung edema and collapse, appears to be perfusion dysregulation occurring in a lung with high gas-volume and compliance. Relatively preserved gas-volumes and, consequently, respiratory compliance [20] may account for the 'silent hypoxemia' observed in other populations [35] and for the nearly complete absence of dyspnea, as per Borg dyspnea scale, observed in our cohort.

The common approach to these patients seems to be a 'conditioned reflex to hypoxemia' of the physicians, established from years of practice in treating ARDS. Indeed, international guidelines and most expert panels recommend treating CARDS as typical ARDS [24, 36, 37]: i.e., low tidal volume and high PEEP. However, these recommendations derive from large randomized controlled trials in which almost $80 \%$ of the patients had an ARDS from bacterial pneumonia and sepsis [38-41], dependably characterized by lung edema, compression atelectasis and the low gas-volumes consistent with the "baby lung". Certainly, in these patients, low tidal volume helps prevent excessive strain of the baby lung and high PEEP maintains open the otherwise atelectatic tissue. In our study population the characteristics of CARDS were significantly different: edema was minimal as shown by the lung weight, the lung collapse is likely negligible as inferred from the small amount of non-aerated tissue and by the unchanged esophageal pressure swing during the PEEP test. This differs from the decreased swings that have been observed in typical, recruitable ARDS [42-44]. Therefore, the bulk of data suggest that the use of higher PEEP may be useless or even harmful at this stage of the disease.

\section{Limitations}

Most of the results of this study are straightforward, as quantitative CT scan analysis and arterial blood gas analysis are standardized tests. Possible controversies may derive from the computation of total lung stress, which includes the effects of PEEP. We consider this choice mandatory as PEEP, being a pressure, induces a counterforce in the lung tissues, i.e., stress. A possible limitation, however, may be the use of the value of 0.7 as the ratio between lung and total respiratory system elastance, to compute the total stress. This ratio, however, is the average found among ARDS populations [16, 45]. Finally, given the low number of intubated patients in our population, some of the subgroup analyses suffer from low statistical power and should be considered more as hypothesis generating than a proof of a cause-effect relationship.

\section{Conclusions}

This study suggests that the total lung stress is independently associated with outcome in early CARDS. Although our data do not allow the determination of whether that stress is a consequence of or a cofactor for disease progression, it appears to be prudent to minimize stress at this stage of the disease. 
Supplementary Information

The online version contains supplementary material available at https://doi. org/10.1007/s00134-021-06519-7.

\begin{abstract}
Author details
${ }^{1}$ Department of Anesthesiology and Intensive Care, ASST Santi e Paolo Hospital, University of Milan, Milan, Italy. ${ }^{2}$ Department of Anesthesiology, Medical University of Göttingen, University Medical Center Göttingen, Robert Koch Straße 40, 37075 Göttingen, Germany. ${ }^{3}$ Department of Anesthesiology, Intensive Care and Emergency Medicine Donau-Isar-Klinikum Deggendorf, Deggendorf, Germany. ${ }^{4}$ Department of Adult Critical Care, Guy's and St Thomas' NHS Foundation Trust, Health Centre for Human and Applied Physiological Sciences, London, UK. ${ }^{5}$ Department of Pulmonary and Critical Care Medicine, University of Minnesota and Regions Hospital, St. Paul, MN, USA. ${ }^{6}$ Respiratory Unit, San Paolo Hospital, Dipartimento Scienze della Salute, Università degli Studi di Milano, Milan, Italy.
\end{abstract}

\section{Authors contributions}

Conception and design: SC, DC, MQ, SC, and LG. Data collection: EG, PP, TP, IS, SR, FR, SL, SG, MMO, and PH. Analysis and interpretation: MB, LS, KM, LC, JJM, $S C$, and LG. All the authors edited and approved the manuscript.

\section{Funding}

Open Access funding enabled and organized by Projekt DEAL. We would like to thank Sartorius AG, Göttingen, Germany and Mr. Massimo Fileni for an unrestricted grant for lung injury-related research towards the Department of Anesthesiology of Göttingen University Medical Center.

\section{Availability of data and material}

Dataset available upon reasonable request.

\section{Declarations}

\section{Conflicts of interest}

LG reports a consultancy for General Electrics and SIDAM. He also receives lecture fees from Estor and Dimar. LS reports financial relationships with Medtronic, Ferrer Deutschland and Merck.

\section{Ethical approval}

The study was approved by the local ethical board (Comitato Etico Milano Area I; 17263/2020- 2020/ST/095), and informed consent was acquired from each patient.

\section{Open Access}

This article is licensed under a Creative Commons Attribution-NonCommercial 4.0 International License, which permits any non-commercial use, sharing, adaptation, distribution and reproduction in any medium or format, as long as you give appropriate credit to the original author(s) and the source, provide a link to the Creative Commons licence, and indicate if changes were made. The images or other third party material in this article are included in the article's Creative Commons licence, unless indicated otherwise in a credit line to the material. If material is not included in the article's Creative Commons licence and your intended use is not permitted by statutory regulation or exceeds the permitted use, you will need to obtain permission directly from the copyright holder. To view a copy of this licence, visit http://creativecommons.org/licen ses/by-nc/4.0/.

\section{Publisher's Note}

Springer Nature remains neutral with regard to jurisdictional claims in published maps and institutional affiliations.

Received: 28 June 2021 Accepted: 27 August 2021

Published online: 16 September 2021

\section{References}

1. Ranieri VM, Rubenfeld GD, Thompson BT, Ferguson ND, Caldwell E, Fan E, Camporota L, Slutsky AS (2012) Acute respiratory distress syndrome: the Berlin Definition. JAMA. https://doi.org/10.1001/jama.2012.5669

2. Gattinoni L, Coppola S, Cressoni M, Busana M, Rossi S, Chiumello D (2020) Covid-19 Does not lead to a "typical" acute respiratory distress syndrome. Am J Respir Crit Care Med. https://doi.org/10.1007/s00134-020-06281-2

3. Chiumello D, Busana M, Coppola S, Romitti F, Formenti P, Bonifazi M, Pozzi T, Palumbo MM, Cressoni M, Herrmann P, Meissner K, Quintel M, Camporota L, Marini JJ, Gattinoni L (2020) Physiological and quantitative CTscan characterization of COVID-19 and typical ARDS: a matched cohort study. Intensive Care Med. https://doi.org/10.1007/s00134-020-06281-2

4. Marini JJ, Gattinoni L (2020) Management of COVID-19 Respiratory Distress. JAMA. https://doi.org/10.1001/jama.2020.6825

5. Gattinoni L, D'Andrea L, Pelosi P, Vitale G, Pesenti A, Fumagalli R (1993) Regional effects and mechanism of positive end-expiratory pressure in early adult respiratory distress syndrome. JAMA. https://doi.org/10.1001/ jama.1993.03500160092039

6. Ashbaugh DG, Bigelow DB, Petty TL, Levine BE (1967) Acute respiratory distress in adults. Lancet 2:319-323

7. Otis AB, Fenn WO, Rahn H (1950) Mechanics of breathing in man. J Appl Physiol 2:592-607

8. Brochard L, Slutsky A, Pesenti A (2017) Mechanical ventilation to minimize progression of lung injury in acute respiratory failure. Am J Respir Crit Care Med 195:438-442

9. Mascheroni D, Kolobow T, Fumagalli R, Moretti MP, Chen V, Buckhold D (1988) Acute respiratory failure following pharmacologically induced hyperventilation: an experimental animal study. Intensive Care Med 15:8-14

10. Barach AL, Martin J, Eckman M (1938) Positive pressure respiration and its application to the treatment of acute pulmonary edema*. Ann Intern Med 12:754-795

11. Gattinoni $L$, Tonetti $T$, Cressoni $M$, Cadringher $P$, Herrmann $P$, Moerer $O$, Protti A, Gotti M, Chiurazzi C, Carlesso E, Chiumello D, Quintel M (2016) Ventilator-related causes of lung injury: the mechanical power. Intensive Care Med 42:1567-1575

12. Akoumianaki E, Maggiore SM, Valenza F, Bellani G, Jubran A, Loring SH, Pelosi P, Talmor D, Grasso S, Chiumello D, Guerin C, Patroniti N, Ranieri VM, Gattinoni L, Nava S, Terragni PP, Pesenti A, Tobin M, Mancebo J, Brochard L, Group PW (2014) The application of esophageal pressure measurement in patients with respiratory failure. Am J Respir Crit Care Med 189:520-531

13. Patel BK, Wolfe KS, Pohlman AS, Hall JB, Kress JP (2016) Effect of noninvasive ventilation delivered by helmet vs face mask on the rate of endotracheal intubation in patients with acute respiratory distress syndrome: a randomized clinical trial. JAMA 315:2435-2441

14. Maiolo G, Collino F, Vasques F, Rapetti F, Tonetti T, Romitti F, Cressoni M, Chiumello D, Moerer O, Herrmann P, Friede T, Quintel M, Gattinoni L (2018) Reclassifying acute respiratory distress syndrome. Am J Respir Crit Care Med 197:1586-1595

15. Gattinoni L, Carlesso E, Cadringher P, Valenza F, Vagginelli F, Chiumello D (2003) Physical and biological triggers of ventilator-induced lung injury and its prevention. Eur Respir J. https://doi.org/10.1183/09031936.03. 00021303

16. Jardin F, Genevray B, Brun-Ney D, Bourdarias JP (1985) Influence of lung and chest wall compliances on transmission of airway pressure to the pleural space in critically ill patients. Chest 88:653-658

17. Gattinoni L, Marini JJ, Collino F, Maiolo G, Rapetti F, Tonetti T, Vasques F, Quintel M (2017) The future of mechanical ventilation: lessons from the present and the past. Crit Care 21:183

18. Group RC, Horby P, Lim WS, Emberson JR, Mafham M, Bell JL, Linsell L, Staplin N, Brightling C, Ustianowski A, Elmahi E, Prudon B, Green C, Felton T, Chadwick D, Rege K, Fegan C, Chappell LC, Faust SN, Jaki T, Jeffery K, Montgomery A, Rowan K, Juszczak E, Baillie JK, Haynes R, Landray MJ (2021) Dexamethasone in hospitalized patients with Covid-19. N Engl J Med 384:693-704 
19. Rouby JJ, Puybasset L, Cluzel P, Richecoeur J, Lu Q, Grenier P (2000) Regional distribution of gas and tissue in acute respiratory distress syndrome. II. Physiological correlations and definition of an ARDS Severity Score. CT Scan ARDS Study Group. Intensive Care Med 26:1046-1056

20. Gattinoni L, Pesenti A, Avalli L, Rossi F, Bombino M (1987) Pressurevolume curve of total respiratory system in acute respiratory failure. Computed tomographic scan study. Am Rev Respir Dis. https://doi.org/ 10.1164/ajrccm/136.3.730

21. Malbouisson LM, Muller JC, Constantin JM, Lu Q, Puybasset L, Rouby J, Group CTSAS (2001) Computed tomography assessment of positive endexpiratory pressure-induced alveolar recruitment in patients with acute respiratory distress syndrome. Am J Respir Crit Care Med 163:1444-1450

22. Gattinoni L, Pesenti A (2005) The concept of "baby lung."Intensive Care Med. https://doi.org/10.1007/s00134-005-2627-z

23. Ziehr DR, Alladina J, Petri CR, Maley JH, Moskowitz A, Medoff BD, Hibbert KA, Thompson BT, Hardin CC (2020) Respiratory pathophysiology of mechanically ventilated patients with covid-19: a cohort study. Am J Respir Crit Care Med. https://doi.org/10.1164/rccm.202004-1163LE

24. Fan E, Beitler JR, Brochard L, Calfee CS, Ferguson ND, Slutsky AS, Brodie D (2020) COVID-19-associated acute respiratory distress syndrome: is a different approach to management warranted? Lancet Respir Med. https:// doi.org/10.1016/S2213-2600(20)30304-0

25. Grasselli G, Tonetti T, Protti A, Langer T, Girardis M, Bellani G, Laffey J, Carrafiello G, Carsana L, Rizzuto C, Zanella A, Scaravilli V, Pizzilli G, Grieco DL, Di Meglio L, de Pascale G, Lanza E, Monteduro F, Zompatori M, Filippini C, Locatelli F, Cecconi M, Fumagalli R, Nava S, Vincent JL, Antonelli M, Slutsky AS, Pesenti A, Ranieri VM (2020) Pathophysiology of COVID-19-associated acute respiratory distress syndrome: a multicentre prospective observational study. Lancet Respir Med. https://doi.org/10.1016/S2213-2600(20) 30370-2

26. Goligher EC, Ranieri VM, Slutsky AS (2021) Is severe COVID-19 pneumonia a typical or atypical form of ARDS? And does it matter? Intensive Care Med 47:83-85

27. Busana M, Giosa L, Cressoni M, Gasperetti A, Di Girolamo L, Martinelli A, Sonzogni A, Lorini L, Palumbo MM, Romitti F, Gattarello S, Steinberg I, Herrmann P, Meissner K, Quintel M, Gattinoni L (1985) (2021) The impact of ventilation-perfusion inequality in COVID-19: a computational model. J Appl Physiol 130:865-876

28. Patel BV, Arachchillage DJ, Ridge CA, Bianchi P, Doyle JF, Garfield B, Ledot S, Morgan C, Passariello M, Price S, Singh S, Thakuria L, Trenfield S, Trimlett R, Weaver C, Wort SJ, Xu T, Padley SPG, Devaraj A, Desai SR (2020) Pulmonary angiopathy in severe COVID-19: physiologic, imaging, and hematologic observations. Am J Respir Crit Care Med 202:690-699

29. Santamarina MG, Boisier D, Contreras R, Baque M, Volpacchio M, Beddings I (2020) COVID-19: a hypothesis regarding the ventilation-perfusion mismatch. Crit Care 24:395

30. Ramos CD, Fernandes AP, Souza SPM, Fujiwara M, Tobar N, Dertkigil SSJ, Takahashi MES, Goncales ESL, Trabasso P, Zantut-Wittmann DE (2021) Simultaneous imaging of lung perfusion and glucose metabolism in COVID-19 pneumonia. Am J Respir Crit Care Med 203:1186-1187

31. Bos $L$ (2020) COVID19 related acute respiratory distress syndrome: not so atypical. Am J Respir Crit Care Med. https://doi.org/10.1164/rccm. 202004-1423LE

32. Gattinoni L, Chiumello D, Caironi P, Busana M, Romitti F, Brazzi L, Camporota L (2020) COVID-19 pneumonia: different respiratory treatment for different phenotypes. Intensive Care Med. https://doi.org/10.1007/ s00134-020-06033-2

33. Li J, Huang DQ, Zou B, Yang H, Hui WZ, Rui F, Yee NTS, Liu C, Nerurkar SN Kai JCY, Teng MLP, Li X, Zeng H, Borghi JA, Henry L, Cheung R, Nguyen $\mathrm{MH}$ (2021) Epidemiology of COVID-19: a systematic review and metaanalysis of clinical characteristics, risk factors, and outcomes. J Med Virol 93:1449-1458
34. Tonelli R, Busani S, Tabbi L, Fantini R, Castaniere I, Biagioni E, Mussini C, Girardis M, Clini E, Marchioni A (2021) Inspiratory effort and lung mechanics in spontaneously breathing patients with acute respiratory failure due to COVID-19: a matched control study. Am J Respir Crit Care Med. https:// doi.org/10.1164/rccm.202104-1029LE

35. Busana M, Gasperetti A, Giosa L, Forleo GB, Schiavone M, Mitacchione G, Bonino C, Villa P, Galli M, Tondo C, Saguner A, Steiger P, Curnis A, Dello Russo A, Pugliese F, Mancone M, Marini JJ, Gattinoni L (2021) Prevalence and outcome of silent hypoxemia in COVID-19. Minerva Anestesiol 87:325-333

36. Alhazzani W, Moller MH, Arabi YM, Loeb M, Gong MN, Fan E, Oczkowski S, Levy MM, Derde L, Dzierba A, Du B, Aboodi M, Wunsch H, Cecconi M, Koh Y, Chertow DS, Maitland K, Alshamsi F, Belley-Cote E, Greco M, Laundy M, Morgan JS, Kesecioglu J, McGeer A, Mermel L, Mammen MJ, Alexander PE, Arrington A, Centofanti JE, Citerio G, Baw B, Memish ZA, Hammond N, Hayden FG, Evans L, Rhodes A (2020) Surviving sepsis campaign: guidelines on the management of critically ill adults with Coronavirus disease 2019 (COVID-19). Crit Care Med 48:e440-e469

37. National Institutes of Health, COVID-19 Treatment Guidelines Panel (2021) Coronavirus Disease 2019 (COVID-19) Treatment Guidelines. https://www. covid19treatmentguidelines.nih.gov/. Accessed 8 Aug 2021

38. Acute Respiratory Distress Syndrome N, Brower RG, Matthay MA, Morris A, Schoenfeld D, Thompson BT, Wheeler A (2000) Ventilation with lower tidal volumes as compared with traditional tidal volumes for acute lung injury and the acute respiratory distress syndrome. N Engl J Med 342:1301-1308

39. Brower RG, Lanken PN, MacIntyre N, Matthay MA, Morris A, Ancukiewicz M, Schoenfeld D, Thompson BT, National Heart L, Blood Institute ACTN (2004) Higher versus lower positive end-expiratory pressures in patients with the acute respiratory distress syndrome. N Engl J Med 351:327-336

40. Writing Group for the Alveolar Recruitment for Acute Respiratory Distress Syndrome Trial I, Cavalcanti AB, Suzumura EA, Laranjeira LN, Paisani DM, Damiani LP, Guimaraes HP, Romano ER, Regenga MM, Taniguchi LNT, Teixeira C, Pinheiro de Oliveira R, Machado FR, Diaz-Quijano FA, Filho MSA, Maia IS, Caser EB, Filho WO, Borges MC, Martins PA, Matsui M, OspinaTascon GA, Giancursi TS, Giraldo-Ramirez ND, Vieira SRR, Assef M, Hasan MS, Szczeklik W, Rios F, Amato MBP, Berwanger O, Ribeiro de Carvalho CR (2017) Effect of lung recruitment and titrated positive end-expiratory pressure (PEEP) vs low PEEP on mortality in patients with acute respiratory distress syndrome: a randomized clinical trial. JAMA 318:1335-1345

41. Mercat A, Richard JC, Vielle B, Jaber S, Osman D, Diehl JL, Lefrant JY, Prat G, Richecoeur J, Nieszkowska A, Gervais C, Baudot J, Bouadma L, Brochard L, Expiratory Pressure Study G (2008) Positive end-expiratory pressure setting in adults with acute lung injury and acute respiratory distress syndrome: a randomized controlled trial. JAMA 299:646-655

42. Morais CCA, Koyama Y, Yoshida T, Plens GM, Gomes S, Lima CAS, Ramos OPS, Pereira SM, Kawaguchi N, Yamamoto H, Uchiyama A, Borges JB, Vidal Melo MF, Tucci MR, Amato MBP, Kavanagh BP, Costa ELV, Fujino Y (2018) High positive end-expiratory pressure renders spontaneous effort noninjurious. Am J Respir Crit Care Med 197:1285-1296

43. Borges JB, Morais CCA, Costa ELV (2019) High PEEP may have reduced injurious transpulmonary pressure swings in the ROSE trial. Crit Care 23:404

44. L'Her E, Deye N, Lellouche F, Taille S, Demoule A, Fraticelli A, Mancebo J, Brochard L (2005) Physiologic effects of noninvasive ventilation during acute lung injury. Am J Respir Crit Care Med 172:1112-1118

45. Chiumello D, Carlesso E, Cadringher P, Caironi P, Valenza F, Polli F, Tallarini F, Cozzi P, Cressoni M, Colombo A, Marini JJ, Gattinoni L (2008) Lung stress and strain during mechanical ventilation for acute respiratory distress syndrome. Am J Respir Crit Care Med. https://doi.org/10.1164/rccm. 200710-15890C 